\title{
Influence of soil texture and crop management on the productivity of miscanthus (Miscanthus $\times$ giganteus Greef et Deu.) in the Mediterranean
}

\author{
NERI RONCUCCI ${ }^{1}$, NICOLETTA NASSI O DI NASSO ${ }^{1}$, ENRICO BONARI ${ }^{1,2}$ and \\ GIORGIO RAGAGLINI ${ }^{1}$ \\ ${ }^{1}$ Institute of Life Sciences, Scuola Superiore Sant'Anna, Piazza Martiri della Libertà 33, Pisa 56127, Italy, ${ }^{2}$ CRIBE - Centro di \\ Ricerche Interuniversitario Biomasse da Energia, Via Vecchia Livornese 784, Pisa 56127, Italy
}

\begin{abstract}
Biomass productivity is the main favorable trait of candidate bioenergy crops. Miscanthus $\times$ giganteus is a promising species, due to its high-yield potential and positive traits including low nutrient requirements and potential for $\mathrm{C}$ sequestration in soils. However, miscanthus productivity appears to be mostly related to water availability in the soil. This is important, particularly in Mediterranean regions where the risk of summer droughts is high. To date, there have been no studies on miscanthus responses under different soil conditions, while only a few have investigated the role of different crop managements, such as irrigation and nitrogen fertilization, in the Mediterranean. Therefore, the effects of contrasting soil textures (i.e. silty-clay-loam vs. sandy-loam) and alternative agricultural intensification regimes (i.e. rainfed vs. irrigated and 0, 50, $100 \mathrm{~kg} \mathrm{ha}^{-1}$ nitrogen fertilization), on miscanthus productivity were evaluated at three different harvest times for two consecutive years. Our results confirmed the importance of water availability in determining satisfactory yields in Mediterranean environments, and how soil and site characteristics strongly affect biomass production. We found that the aboveground dry yields varied between $5 \mathrm{Mg} \mathrm{ha}^{-1}$ up to $29 \mathrm{Mg} \mathrm{ha}^{-1}$. Conversely, nitrogen fertilization played only a minor role on crop productivity, and high fertilization levels were relatively inefficient. Finally, a marked decrease, of up to $-40 \%$, in the aboveground yield occurred when the harvest time was delayed from autumn to winter. Overall, our results highlighted the importance of determining crop responses on a siteby-site basis, and that decisions on the optimal harvest time should be driven by the biomass end use and other long-term considerations, such as yield stability and the maintenance of soil fertility.
\end{abstract}

Keywords: biomass, energy crop, harvest time, irrigation, leaf area index, leaf litter, nitrogen agronomic efficiency, nitrogen fertilization, yield

Received 30 January 2014; accepted 27 March 2014

\section{Introduction}

Perennial rhizomatous grasses are promising energy crops due to their high productivity, low nutrient requirements, ecosystem services and great potential for C mitigation (Lewandowski et al., 2003a; Rowe et al., 2009; Chum et al., 2011). Miscanthus (Miscanthus x giganteus Greef et Deuter), is a high-yielding C4 perennial grass native to Asia and is characterized by vigorous growth and high adaptability in a wide range of European conditions (Clifton-Brown et al., 2001; Lewandowski et al., 2003a; Mantineo et al., 2009). In fact, dry yields of miscanthus without irrigation range from 10 to 15 $\mathrm{Mg} \mathrm{ha}{ }^{-1}$ in northern and central Europe to more than 25

Correspondence: Neri Roncucci, tel. 0039050 883512, fax 0039050 883526, e-mail n.roncucci@sssup.it
$\mathrm{Mg} \mathrm{ha}^{-1}$ in southern Europe (Lewandowski et al., 2003a; Angelini et al., 2009; Zub \& Brancourt-Hulmel, 2010).

However, productivity of miscanthus is largely related to precipitation and the soil moisture available (Kahle et al., 2001; Richter et al., 2008). This is an important issue, particularly in Mediterranean regions where there is a high risk of summer droughts. Irrigation could thus be an important technique to increase miscanthus yields at sites with poor water availability (Heaton et al., 2004; Zub \& Brancourt-Hulmel, 2010). Nevertheless, accessibility to water and its quality is likely to decrease in the near future and much attention is needed on how to allocate water for different uses (Wallace, 2000).

To date, in the Mediterranean there has been no research on miscanthus responses under different soil conditions, and particularly on poor, marginal lands, while few studies have evaluated crop productivity in 
response to irrigation. Results from these latter studies suggest that irrigation influences miscanthus yields, but often with among-year variation (Ercoli et al., 1999; Cosentino et al., 2007; Mantineo et al., 2009). Some research has found a positive interaction between irrigation and nitrogen fertilization (Ercoli et al., 1999; Cosentino et al., 2007). However, those results probably depended on the high levels of nitrogen tested (120 and $200 \mathrm{~kg} \mathrm{~N} \mathrm{ha}^{-1}$ ), as other authors, using lower nitrogen fertilization rates ( 50 and $100 \mathrm{~kg} \mathrm{~N} \mathrm{ha}^{-1}$ ), did not find a significant interaction between the two factors (Mantineo et al., 2009). In addition, the majority of European trials have highlighted little or no influence of nitrogen fertilization on miscanthus productivity (Arundale $\mathrm{et}$ al., 2013).

However, the importance of determining miscanthus yield responses to applied $\mathrm{N}$ on a site-by-site basis has been highlighted, since excessive fertilization can lead to a negative environmental impact, e.g. increased GHG emissions, $\mathrm{N}$ leaching and uncertainties when economic assessments are required (Cadoux et al., 2012; Davis et al., 2013; Larsen et al., 2013).

The potential harvest window of miscanthus is wide (Lewandowski et al., 2003a).The optimal harvest period depends on the environmental conditions of the site which influences the start of the crop senescence, field accessibility etc., as well as the conversion process adopted (combustion, bioethanol, etc.) (Karp \& Shield, 2008; Zegada-Lizarazu et al., 2010). When considering the optimal harvest time, trade off has to be made between yield and quality optimization (Lewandowski \& Heinz, 2003). This is particularly relevant for combustion processes, for which biomass losses due to a delayed harvest are preferred in return for a lower mineral content and a lower level of humidity of the biomass itself (Lewandowski \& Kicherer, 1997).

Developing processes for separating, refining and converting lignocellulosic biomass to produce biofuels and biomaterials could make early harvest material attractive (Ragauskas et al., 2006; Karp \& Shield, 2008). From an agronomical perspective, early harvest requires careful analysis, as rhizome nutrient stocks and soil nutrient contents may become depleted, which in turn will affect the biomass production in the long run (Strullu et al., 2011).

Overall, biomass production entails investigating the appropriate agronomic practices for specific environmental conditions, as crop management is a key factor in sustainable biomass production systems (Zegada-Lizarazu et al., 2010). The aim of this study was thus to deepen the understanding of the influence of contrasting soil textures and alternative agricultural intensification regimes (i.e. irrigation and nitrogen fertilization) on miscanthus productivity at different harvest times.

\section{Materials and methods}

\section{Site and trial set up}

The research was carried out at the Interdepartmental Centre for Agro-Ecological Research (CIRAA) in the Pisa coastal plain (central Italy; latitude $43^{\circ} 68^{\prime} \mathrm{N}$, longitude $10^{\circ} 35^{\prime} \mathrm{E} ; 1 \mathrm{~m}$ a.s.l. and $0 \%$ slope) for two consecutive years, i.e. 2011 and 2012. The area, having originated from land reclamation, is characterized by heterogeneous soil textures, with different soils located within few hundred meters one another, and thus provides a particularly suited site for comparing soil effects under the same environmental conditions (e.g., meteorological conditions, water table depth, etc.).

In spring 2010, two adjacent fields characterized by two contrasting soil textures, i.e. silty-clay-loam $(\mathrm{SiC})$ and sandy-loam (SL), were used to carry out two experiments:

- Experiment 1: three main plots were arranged in the SiC soil and three in the SL soil. Within each main plot, three nitrogen fertilization levels [0 $\left(\mathrm{N}_{0}\right), 50\left(\mathrm{~N}_{50}\right), 100\left(\mathrm{~N}_{100}\right)$ $\mathrm{kg} \mathrm{ha}^{-1}$ ] were randomly assigned as subplots (size $6.5 \times 5.0 \mathrm{~m})$

- Experiment 2 was set up on the SiC soil. Main plots (three replicates) were assigned to two irrigation regimes: $0 \%$ $\left(\mathrm{ET}_{0}\right)$ vs. $75 \%\left(\mathrm{ET}_{75}\right)$ of the potential evapotranspiration. Within each main plot, three nitrogen fertilization levels [0 $\left(\mathrm{N}_{0}\right), 50\left(\mathrm{~N}_{50}\right), 100\left(\mathrm{~N}_{100}\right) \mathrm{kg} \mathrm{ha}^{-1}$ ] were randomly identified as subplots (size $6.5 \times 5.0 \mathrm{~m}$ ).

Meteorological data were obtained from the closest weather station $(<500 \mathrm{~m}$ from the experimental site). Soil samples were collected within 0-60 cm of the surface in April 2010 and analyzed for texture, $\mathrm{pH}$, organic matter, total nitrogen, available phosphorus, exchangeable potassium, cation-exchange capacity (CEC) and soil water characteristics (Table 1). The soil was a Typic Xerofluvent, representative of the lower Arno river plain, characterized by a shallow water table never below a $2.5 \mathrm{~m}$ depth even during the driest periods.

Table 1 Soil characteristics at the experimental sites $(0-60 \mathrm{~cm}$; April 2010)

\begin{tabular}{lrr}
\hline & SiC & \multicolumn{1}{c}{ SL } \\
\hline Sand $(2-0.05 \mathrm{~mm})(\%)$ & 18.1 & 78.9 \\
Silt $(0.05-0.002 \mathrm{~mm})(\%)$ & 46.4 & 11.0 \\
Clay $(<0.002 \mathrm{~mm})(\%)$ & 35.5 & 10.1 \\
$\mathrm{pH}(1: 1 \mathrm{w} / \mathrm{v})$ & 8.2 & 7.7 \\
Organic matter (Walkley-Black) (\%) & 1.8 & 0.9 \\
Total nitrogen (Kjeldahl) $\left(\mathrm{g} \mathrm{kg}^{-1}\right)$ & 1.4 & 0.7 \\
Available phosphorus & 69.3 & 116.9 \\
(Olsen) $\left(\mathrm{mg} \mathrm{kg}^{-1}\right)$ & & \\
Exchangeable potassium & 223.7 & 151.7 \\
(Dirks and Scheffer) $\left(\mathrm{mg} \mathrm{kg}^{-1}\right)$ & & \\
CEC (meq $\left.100 \mathrm{~g}^{-1}\right)$ & 22.3 & 8.5 \\
Field capacity $(\% \mathrm{w})$ & 35.3 & 9.7 \\
Wilting point $(\% \mathrm{w})$ & 16.1 & 2.0 \\
\hline
\end{tabular}


Tillage was conducted in the autumn of 2009 by ploughing, followed by rotary harrowing immediately before planting. Crop establishment was carried out on April 22, 2010 using rhizomes, at a density of two plants per $\mathrm{m}^{-2}(1 \times 0.5 \mathrm{~m}$ spacing $)$. No preplant fertilizer was required. Plants were watered throughout the first growing season to get them established. By the end of the first year, the establishment rate was close to 100 percent in all plots. Weeding and pest control were never necessary at any point during the trial.

In both Experiments 1 and 2, nitrogen (urea) fertilization treatments were always performed in the spring, when crops were $0.20-0.30 \mathrm{~m}$ tall. In Experiment 2, water was distributed by drip irrigation. Drip irrigation pipes were placed $1 \mathrm{~m}$ apart and positioned in the inter-rows. The distance of the drippers was $30 \mathrm{~cm}$ with a dripper flow rate of 11 per hour. Daily potential evapotranspiration (ETP) was estimated through the FAO Penman-Monteith equation (Allen et al., 1998) from daily climatic data. Irrigation was scheduled every 2 days.

Table 2 summarizes the principal cultivation phases (emergence, fertilization and harvest dates) and the amount of water (precipitation and irrigation) the crops received.

\section{Measurements}

In both Experiments 1 and 2, productive measurements for the second and third year of growth (i.e. 2011 and 2012 respectively) were collected in three different periods: early autumn $\left(A_{1}\right)$ (i.e. mid October), late autumn $\left(A_{2}\right)$ (i.e. mid November) and winter (W) (i.e. end of January - early February).

At each harvest time, the aboveground biomass was sampled in a $4 \mathrm{~m}^{2}$ area $\left(2 \times 2 \mathrm{~m}^{2}\right.$ subreplicates $)$ and fresh weight was determined. Border plants from the outer rows were not included in the sampling area. Plant subsamples were partitioned into leaves, stems and inflorescence. After partitioning, subsamples were dried at $60{ }^{\circ} \mathrm{C}$ until constant weight to determine the dry matter content and dry biomass yield. Aboveground dry yield was derived as the sum of leaves, stems and inflorescence components.

The agronomic efficiency of the nitrogen fertilization $\left(\mathrm{A}_{\mathrm{E}}, \mathrm{kg}\right.$ $\mathrm{kg}_{\mathrm{N}}{ }^{-1}$ ) was calculated according to Delogu et al. (1998), as:

$$
A_{E}=\frac{Y_{N X}-Y_{N O}}{N_{X}}
$$

where $Y_{N x}$ represents the aboveground dry yield at $N_{x}$ fertilization level, $\mathrm{Y}_{\mathrm{N}}$ the aboveground dry yield receiving no $\mathrm{N}$ fertilization and $N_{x}$ the applied nitrogen fertilization rate. Thus, $A_{E}$ represents the ability of the crop to increase yield in response to $\mathrm{N}$ applied.

In addition, in both years leaf litter on top of the ground was collected at each harvest date in a $2 \mathrm{~m}^{2}$ area. Litter subsamples were dried at $60{ }^{\circ} \mathrm{C}$ until constant weight to obtain the amount of dry leaf litter per unit of area.

Finally, during the growing seasons, the crop canopy development was measured. The leaf area index (LAI) was estimated using a leaf canopy analyzer (SunScan, Delta-T Devices Ltd., Cambridge, UK).

\section{Statistical analysis}

Data were analyzed by a split-split plot ANOVA to evaluate the effect of the main plot (i.e. soil texture in Experiment 1, irrigation in Experiment 2), of the subplot (nitrogen fertilization) and of the sub-subplot (time of harvest) on the aboveground dry yield and the amount of litterfall per unit of area (Gomez \& Gomez, 1984). Tukey's HSD post hoc test was used to separate means. The statistical analysis was performed with $\mathrm{R}$ software (R Core Team, 2013) and the agricolae package (de Mendiburu, 2013).

Table 2 Summary of the principal crop cultivation phases, precipitation, irrigation and $\mathrm{N}$ fertilization dates in Experiment 1 [siltyclay-loam ( $\mathrm{SiC})$ vs. sandy-loam (SL)] and Experiment $2\left[0 \%\left(\mathrm{ET}_{0}\right)\right.$ vs. $75 \%\left(\mathrm{ET}_{75}\right)$ of the potential evapotranspiration] in the second (2011) and third (2012) growing years. $A_{1}, A_{2}$ and $W$ represent early autumn, late autumn and winter harvests, respectively

\begin{tabular}{|c|c|c|c|c|}
\hline & \multicolumn{2}{|l|}{2011} & \multicolumn{2}{|l|}{2012} \\
\hline & $\mathrm{SiC}, \mathrm{SL}, \mathrm{ET}_{0}$ & $\mathrm{ET}_{75}$ & $\mathrm{SiC}, \mathrm{SL}, \mathrm{ET}_{0}$ & $\mathrm{ET}_{75}$ \\
\hline $\mathrm{DOE}^{*}$ & 01 April & & 02 April & \\
\hline \multicolumn{5}{|l|}{$\mathrm{DOH}^{*}$} \\
\hline $\mathrm{A}_{1}$ & 12 October & & 2 October & \\
\hline $\mathrm{A}_{2}$ & 10 November & & 26 November & \\
\hline $\mathrm{W}$ & 25 January & & 20 February & \\
\hline $\mathrm{N}$ fertilization date & 19 April & & 17 April & \\
\hline \multicolumn{5}{|l|}{ Precipitation $(\mathrm{mm}) \dagger$} \\
\hline $\mathrm{A}_{1}$ & 164.2 & & 395.8 & \\
\hline $\mathrm{A}_{2}$ & 223.0 & & 695.8 & \\
\hline W & 373.8 & & 1155.6 & \\
\hline Irrigation (mm) & - & 390 & - & 342 \\
\hline Start of irrigation & - & 14 June & - & 21 June \\
\hline End of irrigation & - & 02 November & - & 19 September \\
\hline
\end{tabular}

*DOE and DOH represent the day of emergence and day of harvest respectively.

$\dagger$ Precipitation are cumulated daily values calculated from DOE to $\mathrm{DOH}$. 


\section{Results}

\section{Meteorological data}

The study site represents a typical Mediterranean climate, with warm dry summers, cool winters and precipitation events concentrated in the autumn and spring. Figure 1 reports the meteorological trend of the second (2011) and third (2012) growing seasons. Compared to the 20-year term (1986-2005) precipitation trend $\left(876 \mathrm{~mm} \mathrm{yr}^{-1}\right), 2011$ was a dry year, with $30 \%$ less precipitation than the long-term average $(627 \mathrm{~mm})$, while 2012 was in line with the long-term trend, with a slightly higher precipitation $(+7 \%, 936 \mathrm{~mm})$. In accordance with Bagnouls \& Gaussen (1957), dry periods occurred in 2011 and 2012 during the spring-summer periods. As a general trend, the air temperatures increased from March to August. In the period of investigation, the average yearly temperature was $14.7^{\circ} \mathrm{C}$, temperatures lower than $0{ }^{\circ} \mathrm{C}$ were recorded in February 2012 only, and maximum values over $30{ }^{\circ} \mathrm{C}$ were quite frequent in July and August.

\section{Experiment 1 - Contrasting soil textures}

In the second year of growth (2011) crops growing in $\mathrm{SiC}$ soil showed a significantly higher aboveground dry yield (Table S1) compared to crops growing in SL soil (19.1 vs. $10.9 \mathrm{Mg} \mathrm{ha}^{-1}$ ) (Fig. 2a). In addition, maximum yields were recorded at the $\mathrm{A}_{1}$ harvest $\left(17.4 \mathrm{Mg} \mathrm{ha}^{-1}\right.$ ). On average, switching from $A_{1}$ to $W$ harvest led to a significant reduction in dry biomass yield (-5.7 $\mathrm{Mg} \mathrm{ha}^{-1},-32.8 \%$ ) (Fig. 2b). General trends in biomass productivity were amplified in the third growing year (2012), when miscanthus growing in SL soil was severely influenced by the summer drought which led to premature aboveground senescence, leaf loss and inhibition of flowering. Hence, averaged over the three harvest dates, dry biomass yield in the SL soil was one order of magnitude lower than in the $\mathrm{SiC}$ soil (24.6 vs. 3.9 $\mathrm{Mg} \mathrm{ha}^{-1}$ ). A significant interaction between soil and date of harvest was observed in 2012. In fact, productivity in the SL soil did not significantly decrease from the $A_{1}$ to $W$ harvest (i.e. values remained low, though stable), while miscanthus yield in the $\mathrm{SiC}$ soil did decrease (-11.9 $\mathrm{Mg} \mathrm{ha}^{-1},-40.5 \%$ ) (Fig. 2c).

On the other hand, in both years of investigation no effect of the nitrogen fertilization level on the aboveground dry yield was recorded (Table S1). Averaged over the 2 years, the increase in the aboveground dry yield stood at around $2 \mathrm{Mg} \mathrm{ha}^{-1}$ every $50 \mathrm{~kg} \mathrm{~N}^{-1}$ in the $\mathrm{SiC}$ soil, while it was negligible in the SL soil. As a consequence, the agronomic efficiency of the $\mathrm{N}$ fertilization $\left(\mathrm{A}_{\mathrm{E}}\right)$ reflected mostly differences between soils, rather than among nitrogen fertilization rates (Table 3).

In both years, delayed harvest at $\mathrm{W}$ time significantly $(P<0.001)$ increased miscanthus dry matter concentration compared to autumn $\left(\mathrm{A}_{1}\right.$ and $\left.\mathrm{A}_{2}\right)$ harvests $(+31 \%$ on average). In $\mathrm{W}$, crops in SiC and SL soils had similar aboveground dry matter concentration in 2011 (805 $\mathrm{g} \mathrm{kg}^{-1}$ on average), while the following year (2012) miscanthus growing in the SL soil reached a higher dry matter concentration (around $710 \mathrm{~g} \mathrm{~kg}^{-1}$ ) compared to the $\mathrm{SiC}$ (Table 4).

As expected, litterfall on soil surface increased $(P<0.001)$ steadily from $A_{1}$, reaching maximum values in $\mathrm{W}$ for the 2 years of investigation $\left(3.4 \mathrm{Mg} \mathrm{ha}^{-1}\right.$ on average in 2011 and $4.6 \mathrm{Mg} \mathrm{ha}^{-1}$ on $\mathrm{SiC}$ soil in 2012). The only exception was the 2012 litterfall on SL soil when plants senesced early in the season and maximum leaf

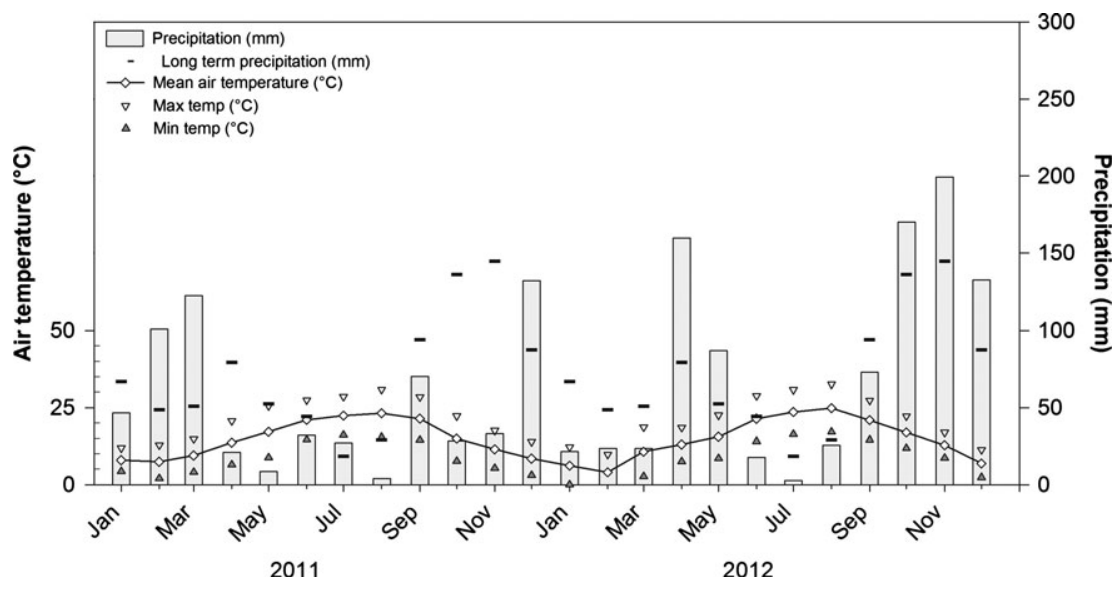

Fig. 1 Monthly and long-term (1986-2007) precipitation, minimum, maximum and mean air temperature in San Piero a Grado (Pisa) in 2011 and 2012. The graph is presented as a Bagnouls \& Gaussen (1957) diagram, to identify dry months, i.e. when precipitation (P) is equal to or less than twice the monthly mean air temperature value $(\mathrm{T})(\mathrm{P} \leq 2 \mathrm{~T})$. 

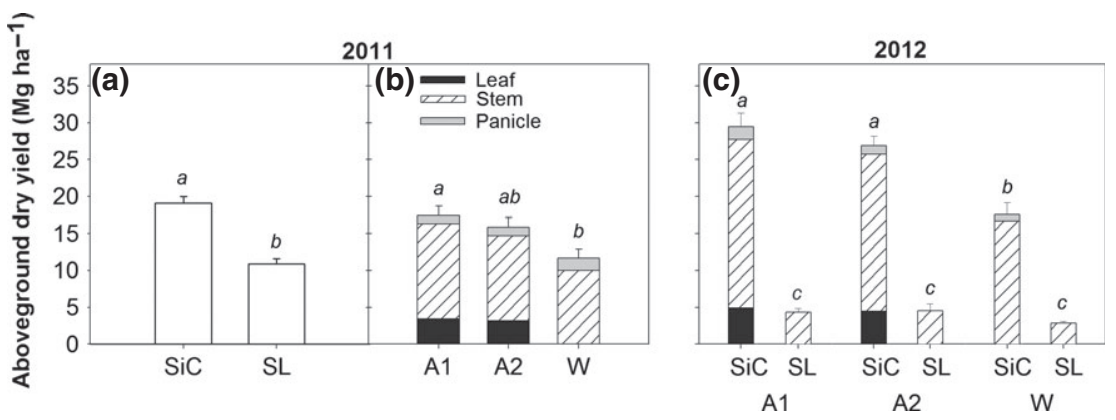

Fig. 2 Aboveground dry yield in the second (2011) and third (2012) growing seasons in Experiment 1. Data are presented according to the ANOVA: (a) significant differences between the two soil textures in 2011 ( $\mathrm{SiC}$ and SL stand for silty-clay-loam and sandy-loam soils respectively); (b) significant differences among the three harvest dates in $2011\left(\mathrm{~A}_{1}, \mathrm{~A}_{2}\right.$ and $\mathrm{W}$ represent early autumn, late autumn and winter harvests, respectively); (c) significant interaction between soil texture and harvest time in 2012. Different letters indicate significant differences at $P<0.05$. Vertical bars represent the SE $(n=3)$.

Table 3 Effect of the nitrogen fertilization rate on the aboveground dry yield and agronomic efficiency of the $\mathrm{N}$ fertilization $\left(A_{E}\right)$ in Experiment 1. Data are averaged over the three harvest dates $\left(A_{1}, A_{2}\right.$ and $\left.W\right)$ and the two growing years (i.e. 2011 and 2012). SiC and SL represent the silty-clay-loam and the sandy-loam soils. $\mathrm{N}_{0}, \mathrm{~N}_{50}, \mathrm{~N}_{100}$ represent 0,50 and $100 \mathrm{~kg}$ $\mathrm{N} \mathrm{ha}^{-1}$, respectively. Standard errors are given in brackets $(n=3)$

\begin{tabular}{llll}
\hline $\begin{array}{l}\text { Soil } \\
\text { texture }\end{array}$ & $\begin{array}{l}\text { f } \\
\text { rate }\end{array}$ & $\begin{array}{l}\text { Aboveground } \\
\text { dry yield } \\
\left(\mathrm{Mg} \mathrm{ha}^{-1}\right)\end{array}$ & $\begin{array}{l}\text { Agronomic } \\
\text { efficiency } \\
\left(\mathrm{kg} \mathrm{kg}_{\mathrm{N}}{ }^{-1}\right)\end{array}$ \\
\hline SiC & $\mathrm{N}_{0}$ & $19.7( \pm 2.2)$ & \\
& $\mathrm{N}_{50}$ & $21.6( \pm 2.2)$ & 38.1 \\
& $\mathrm{~N}_{100}$ & $24.2( \pm 2.0)$ & 44.6 \\
SL & $\mathrm{N}_{0}$ & $7.1( \pm 1.7)$ & \\
& $\mathrm{N}_{50}$ & $8.0( \pm 1.4)$ & 18.9 \\
& $\mathrm{~N}_{100}$ & $7.1( \pm 1.6)$ & 0.4 \\
\hline
\end{tabular}

litter was attained already during the $\mathrm{A}_{1}$, decreasing progressively to $\mathrm{W}$, owing to litter decomposition (Fig. 3).

In terms of the leaf area index (LAI), Fig. 4 shows a comparison of miscanthus grown in $\mathrm{SiC}$ and SL soils and receiving $\mathrm{N}_{0}, \mathrm{~N}_{50}$ and $\mathrm{N}_{100}$ fertilization rates. In 2011, the LAI pattern of crops grown in SiC and SL was similar, i.e. LAI increased until a maximum around July/August, 4.6 and $3.1 \mathrm{~m} \mathrm{~m}^{-2}$ in SiC and SL respectively, and then decreased steadily. In the following year, there was a marked difference between the miscanthus grown in $\mathrm{SiC}$ and SL soils: crops in the $\mathrm{SiC}$ soil showed an increasing trend until August, reaching maximum LAI values of 6.8, while crops in SL soil exhibited decreasing LAI values starting as early as mid-May, and had completely senesced in August. In the SiC soil, increasing levels of $\mathrm{N}$ fertilization led overall to higher LAI values during the midseason (i.e. June-August), thus obtaining increases in maximum LAI around $1 \mathrm{~m}^{2}$ $\mathrm{m}^{-2}$ every $50 \mathrm{~kg} \mathrm{~N}^{-1}$.
Table 4 Dry matter concentration $( \pm \mathrm{SE}, n=3)$ as a function of the harvest time in silty-clay-loam $(\mathrm{SiC})$ and sandy-loam (SL) soils (Experiment 1) for the second (2011) and third (2012) growing seasons. $\mathrm{A}_{1}, \mathrm{~A}_{2}$ and $\mathrm{W}$ represent early autumn, late autumn and winter harvests, respectively. For each year, different superscript letters indicate a significant $(P<0.05)$ interaction between soil texture and harvest time

\begin{tabular}{clc}
\hline & \multicolumn{2}{l}{ Dry matter concentration $\left(\mathrm{g} \mathrm{kg}^{-1}\right)$} \\
\cline { 2 - 3 } & $\mathrm{SiC}$ & $\mathrm{SL}$ \\
\hline 2011 & & \\
$\mathrm{~A}_{1}$ & $521.3( \pm 6.1)^{\mathrm{b}}$ & $487.9( \pm 8.6)^{\mathrm{b}}$ \\
$\mathrm{A}_{2}$ & $525.6( \pm 5.1)^{\mathrm{b}}$ & $494.8( \pm 7.8)^{\mathrm{b}}$ \\
$\mathrm{W}$ & $788.9( \pm 13.1)^{\mathrm{a}}$ & $821.1( \pm 11.7)^{\mathrm{a}}$ \\
& & \\
2012 & & $529.7( \pm 37.4)^{\mathrm{bc}}$ \\
$\mathrm{A}_{1}$ & $493.5( \pm 11.8)^{\mathrm{c}}$ & $442.5( \pm 35.5)^{\mathrm{c}}$ \\
$\mathrm{A}_{2}$ & $528.1( \pm 7.0)^{\mathrm{bc}}$ & $708.2( \pm 10.9)^{\mathrm{a}}$ \\
$\mathrm{W}$ & $609.3( \pm 19.6)^{\mathrm{b}}$ & \\
\hline
\end{tabular}

\section{Experiment 2 - Contrasting irrigation regimes}

In both the second (2011) and third (2012) years of growth, no aboveground yield differences were recorded between the two irrigation treatments (around $20 \mathrm{Mg} \mathrm{ha}^{-1}$ in 2011 and $25 \mathrm{Mg} \mathrm{ha}^{-1}$ in 2012), while harvest time significantly influenced the aboveground dry yield (Table S2). Maximum aboveground dry yields were observed at the $A_{1}$ stage (23.2 and $29.0 \mathrm{Mg} \mathrm{ha}^{-1}$ in 2011 and 2012 respectively), then values decreased until the $\mathrm{W}$ harvest to 16.0 and $18.1 \mathrm{Mg} \mathrm{ha}^{-1}$ in 2011 and 2012 respectively (Fig. 5). Yield losses ranged from 31 to $38 \%$ from $\mathrm{A}_{1}$ to $\mathrm{W}$.

The effect of nitrogen fertilization was observed for the second growth year (2011), when crops receiving 50 and $100 \mathrm{~kg} \mathrm{~N}^{-1}$ yielded significantly (Table S2) higher (21.6 $\mathrm{Mg} \mathrm{ha}^{-1}$ on average) aboveground dry biomass compared to the unfertilized treatment (16.9 


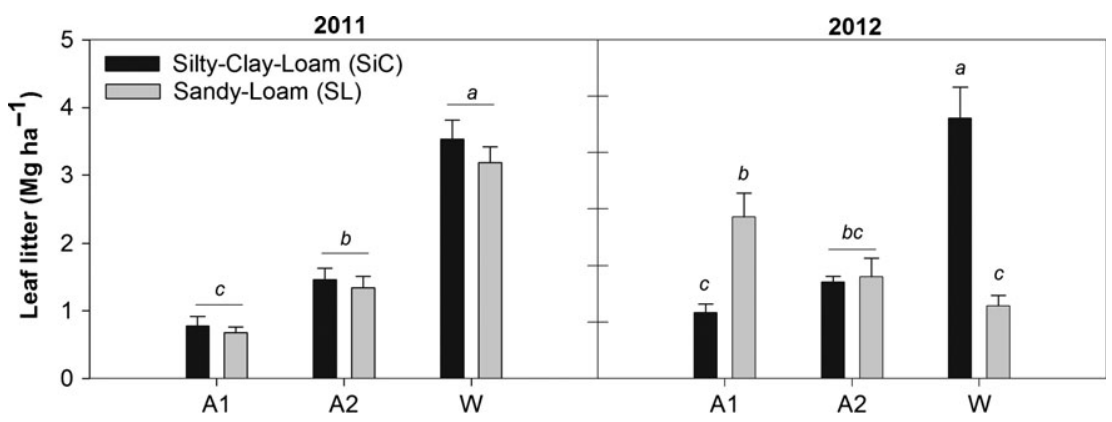

Fig. 3 Leaf litter during the second (2011) and third (2012) year of growth under contrasting soil textures (Experiment 1). $\mathrm{A}_{1}, \mathrm{~A}_{2}$ and W represent early autumn, late autumn and winter harvests, respectively. Different letters indicate significant differences at $P<0.05$. Vertical bars represent the standard error $(n=3)$.

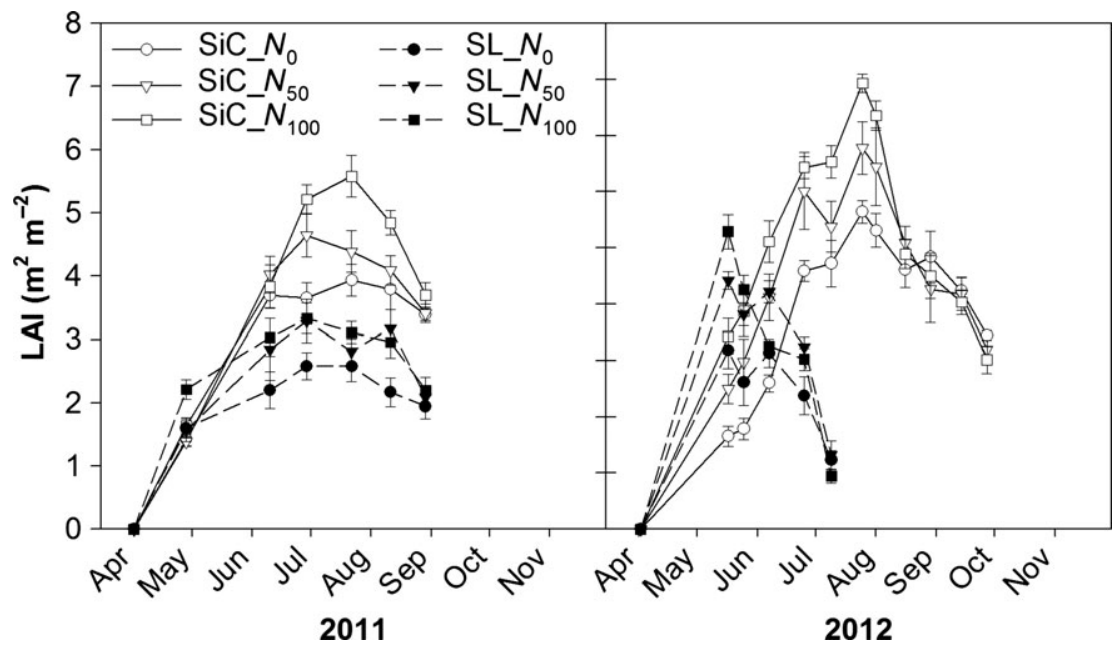

Fig. 4 Dynamics of the leaf area index (LAI) for the second (2011) and third (2012) growing seasons in miscanthus grown on a siltyclay-loam ( $\mathrm{SiC})$ soil and on a sandy-loam (SL) soil and receiving $0\left(\mathrm{~N}_{0}\right), 50\left(\mathrm{~N}_{50}\right)$ and $100\left(\mathrm{~N}_{100}\right) \mathrm{kg} \mathrm{N} \mathrm{ha}^{-1}$. Vertical bars represent the standard error $(n=3)$.

$\mathrm{Mg} \mathrm{ha}^{-1}$ ) (Table 5). Table 5 also reports the agronomic efficiencies of the $\mathrm{N}$ fertilization $\left(\mathrm{A}_{\mathrm{E}}\right)$. Averaged over the irrigation regimes, in 2011 when the crop was supplied with $50 \mathrm{~kg} \mathrm{ha}^{-1}$ of nitrogen, an increase in dry yield around $93 \mathrm{~kg}$ per $\mathrm{kg}$ of nitrogen was recorded. On the other hand, a higher level of $\mathrm{N}$ fertilization, up to $100 \mathrm{~kg} \mathrm{~N} \mathrm{ha}^{-1}$, reduced its agronomic efficiency nearly by half, showing increases in dry yield of around $48 \mathrm{~kg}$ per $\mathrm{kg}$ of applied nitrogen. Conversely, in 2012 the effect of nitrogen fertilization on the aboveground dry yield was not significant, and differences in the $A_{E}$ between the $\mathrm{N}_{50}$ and $\mathrm{N}_{100}$ treatments were much smaller (Table 5).

While no differences were recorded in terms of dry matter concentration between irrigation regimes and among nitrogen fertilization levels, switching from an early to late harvest drastically reduced the moisture content of the crop, thus significantly $(P<0.001$ in both years) increasing its dry matter concentration from around $480-510 \mathrm{~g} \mathrm{~kg}^{-1}$ up to $800 \mathrm{~g} \mathrm{~kg}^{-1}$ in 2011 and $630 \mathrm{~g} \mathrm{~kg}^{-1}$ in 2012 (Table 6).

Concerning the leaf litter, no significant differences were recorded between the two irrigation levels ( $P=0.678$ in 2011 and $P=0.453$ in 2012). Conversely, the amount of leaf litter retrieved on the soil surface increased significantly $\left(P<0.001\right.$ in both years) from $\mathrm{A}_{1}$ to $\mathrm{W}$. Litterfall at $\mathrm{W}$ time accounted for around 3.3 and 4.7 Mg ha ${ }^{-1}$ in 2011 and 2012 respectively (Fig. 6).

Leaf area index dynamics throughout the season were similar in the second (2011) and third (2012) years and matched the trend already reported for miscanthus grown in $\mathrm{SiC}$ soil: on average, maximum LAI was observed around 100 days after emergence, on July 22 and 25 in 2011 and 2012 respectively (Fig. 7). The statistical analysis performed on maximum LAI revealed no influence of the irrigation regime, while a significant effect of nitrogen fertilization was observed in both years (Table S3), with the highest values recorded in 


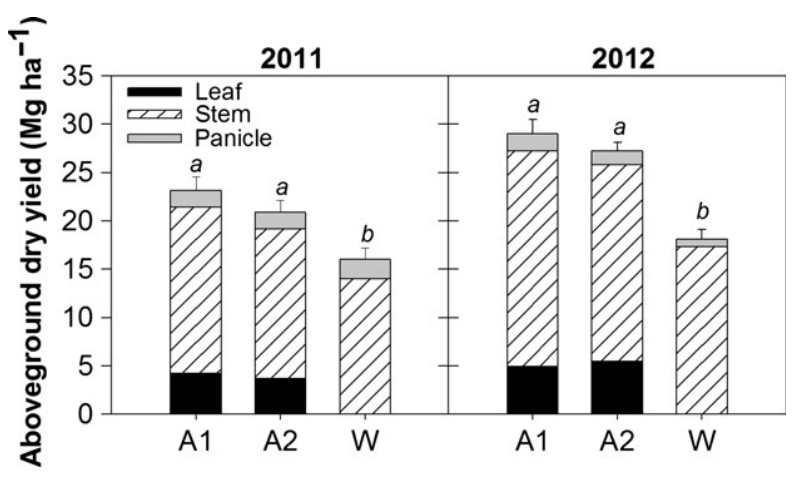

Fig. 5 Aboveground dry yield in the second (2011) and third (2012) growing seasons in Experiment 2. Data are presented according to the ANOVA and report the effect of the harvest time. $A_{1}, A_{2}$ and $W$ represent early autumn, late autumn and winter harvests, respectively. Different letters indicate significant differences at $P<0.05$. Vertical bars represent the SE $(n=3)$.

Table 5 Effect of the nitrogen fertilization rate on the aboveground dry yield and agronomic efficiency of the $\mathrm{N}$ fertilization $\left(A_{E}\right)$ in Experiment 2 for the second (2011) and third (2012) growing seasons. Data are averaged over the two irrigation regimes $\left(\mathrm{ET}_{0}\right.$ and $\left.\mathrm{ET}_{75}\right)$ and the three harvest dates $\left(\mathrm{A}_{1}, \mathrm{~A}_{2}\right.$ and W). $\mathrm{N}_{0}, \mathrm{~N}_{50}, \mathrm{~N}_{100}$ represent 0,50 and $100 \mathrm{~kg} \mathrm{~N} \mathrm{ha}^{-1}$, respectively. Different superscript letters indicate significant differences at $P<0.05$. Standard errors are given in brackets $(n=3)$

\begin{tabular}{llll}
\hline Year & $\begin{array}{l}\mathrm{N} \\
\text { fertilization } \\
\text { rate }\end{array}$ & $\begin{array}{l}\text { Aboveground } \\
\text { dry yield } \\
\left(\mathrm{Mg} \mathrm{ha}^{-1}\right)\end{array}$ & $\begin{array}{l}\text { Agronomic } \\
\text { efficiency } \\
\left(\mathrm{kg} \mathrm{kg}_{\mathrm{N}}{ }^{-1}\right)\end{array}$ \\
\hline 2011 & $\mathrm{~N}_{0}$ & $16.9( \pm 2.2)^{\mathrm{b}}$ & \\
& $\mathrm{N}_{50}$ & $21.5( \pm 2.2)^{\mathrm{a}}$ & 93.3 \\
& $\mathrm{~N}_{100}$ & $21.7( \pm 2.5)^{\mathrm{a}}$ & 48.2 \\
2012 & $\mathrm{~N}_{0}$ & $23.5( \pm 2.9)$ & \\
& $\mathrm{N}_{50}$ & $25.2( \pm 2.5)$ & 34.8 \\
& $\mathrm{~N}_{100}$ & $25.6( \pm 3.0)$ & 20.9 \\
\hline
\end{tabular}

miscanthus receiving 50 and $100 \mathrm{~kg} \mathrm{~N} \mathrm{ha}^{-1}$ (around $4.7 \mathrm{~m} \mathrm{~m}^{-2}$ in 2011 and $7.7 \mathrm{~m} \mathrm{~m}^{-2}$ in 2012).

\section{Discussion}

Our main objective was to investigate the aboveground productivity of miscanthus in response to different soil textures (silty-clay-loam vs. sandy-loam), and crop management (irrigation and nitrogen fertilization), at different harvest times. The rationale for an early autumn harvest $\left(A_{1}\right)$ was based on the fact that, in Mediterranean environments, the full plant flowering phase occurs in September/October, and flowering corresponds to the maximum harvestable aboveground biomass yield (Petrini et al., 1996; Cosentino et al., 2007;
Table 6 Dry matter concentration $( \pm \mathrm{SE}, n=3)$ as a function of the harvest time in Experiment 2 for the second (2011) and third (2012) growing seasons. Data are averaged over the two irrigation regimes $\left(\mathrm{ET}_{0}\right.$ and $\left.\mathrm{ET}_{75}\right)$ and the three $\mathrm{N}$ fertilization levels $\left(N_{0}, N_{50}\right.$ and $\left.N_{100}\right) . A_{1}, A_{2}$ and $W$ represent early autumn, late autumn and winter harvests, respectively. For each year, different superscript letters indicate significant differences at $P<0.05$

\begin{tabular}{lll}
\hline & $\begin{array}{l}\text { Dry matter } \\
\text { concentration }\left(\mathrm{g} \mathrm{kg}^{-1}\right)\end{array}$ & \\
& 2011 & 2012 \\
\hline $\mathrm{A}_{1}$ & $511.2( \pm 4.6)^{\mathrm{b}}$ & $476.2( \pm 9.0)^{\mathrm{c}}$ \\
$\mathrm{A}_{2}$ & $517.0( \pm 5.1)^{\mathrm{b}}$ & $528.8( \pm 4.3)^{\mathrm{b}}$ \\
$\mathrm{W}$ & $803.0( \pm 9.1)^{\mathrm{a}}$ & $631.6( \pm 13.5)^{\mathrm{a}}$ \\
\hline
\end{tabular}

Nassi o Di Nasso et al., 2011). On the other hand, late autumn $\left(\mathrm{A}_{2}\right)$ and winter $(\mathrm{W})$ harvests provide useful comparisons with literature data, as well as explaining variations in biomass yield and dry matter concentration with delayed harvests (Zub \& Brancourt-Hulmel, 2010).

Miscanthus yields may vary considerably depending on the environmental conditions of the study site, the management practices and harvest time (Brosse et al., 2012). Studies in Europe and United States and summarized by Heaton et al. (2010) showed how the harvestable biomass of miscanthus ranges between 5 and 55 $\mathrm{Mg} \mathrm{ha}{ }^{-1}$. In southern Europe, under rainfed conditions, miscanthus aboveground dry yields are generally around 25-30 $\mathrm{Mg} \mathrm{ha}^{-1}$ (Angelini et al., 2009), while irrigated conditions led to yields of around $36 \mathrm{Mg} \mathrm{ha}^{-1}$ in Portugal (Clifton-Brown et al., 2001), 34-38 $\mathrm{Mg} \mathrm{ha}^{-1}$ in Italy (Ercoli et al., 1999; Cosentino et al., 2007) and 38-44 $\mathrm{Mg} \mathrm{ha}{ }^{-1}$ in Greece (Danalatos et al., 1996, 2007).

The results obtained in our experiments confirmed the importance of water availability in determining satisfactory miscanthus yields in a Mediterranean environment. In fact, miscanthus plantations in soils characterized by a poor water holding capacity (i.e. SL soil) were severely affected after three growing years, with harvestable dry yields lower than $5 \mathrm{Mg} \mathrm{ha}^{-1}$. This is consistent with our observations regarding LAI throughout 2012 when crops grown in SL soil ended as soon as mid-July, leading to premature senescence. In miscanthus, drought conditions may cause a decrease in LAI, even at higher latitudes (Clifton-Brown et al., 2000), and a significant reduction in belowground biomass (Clifton-Brown \& Lewandowski, 2000). Since aboveground resources are not mobilized until midsummer, stress conditions during growth considerably affect the remobilization of nutrients and carbohydrates from above- to belowground organs, in turn affecting 


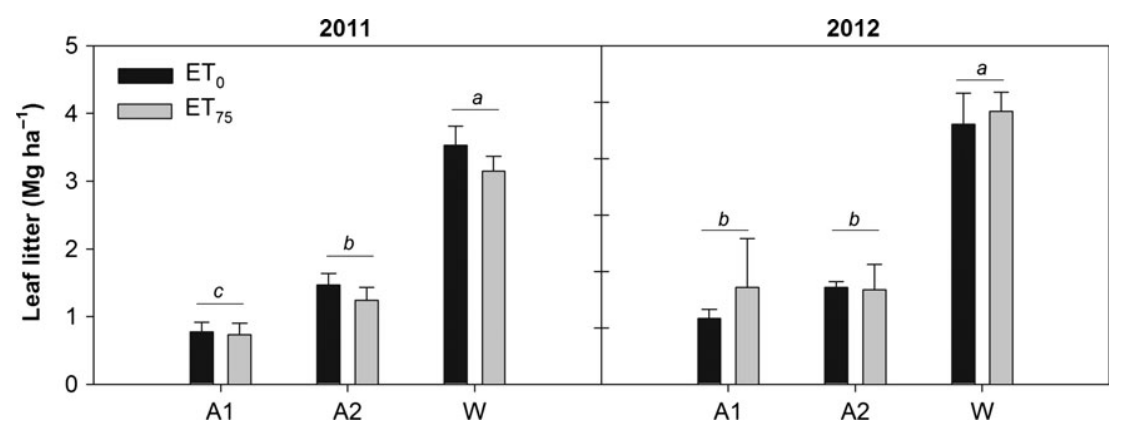

Fig. 6 Leaf litter during the second (2011) and third (2012) year of growth under contrasting irrigation regimes (Experiment 2). $A_{1}$, $\mathrm{A}_{2}$ and $\mathrm{W}$ represent early autumn, late autumn and winter harvests, respectively. Different letters indicate significant differences at $P<0.05$. Vertical bars represent the SE $(n=3)$.

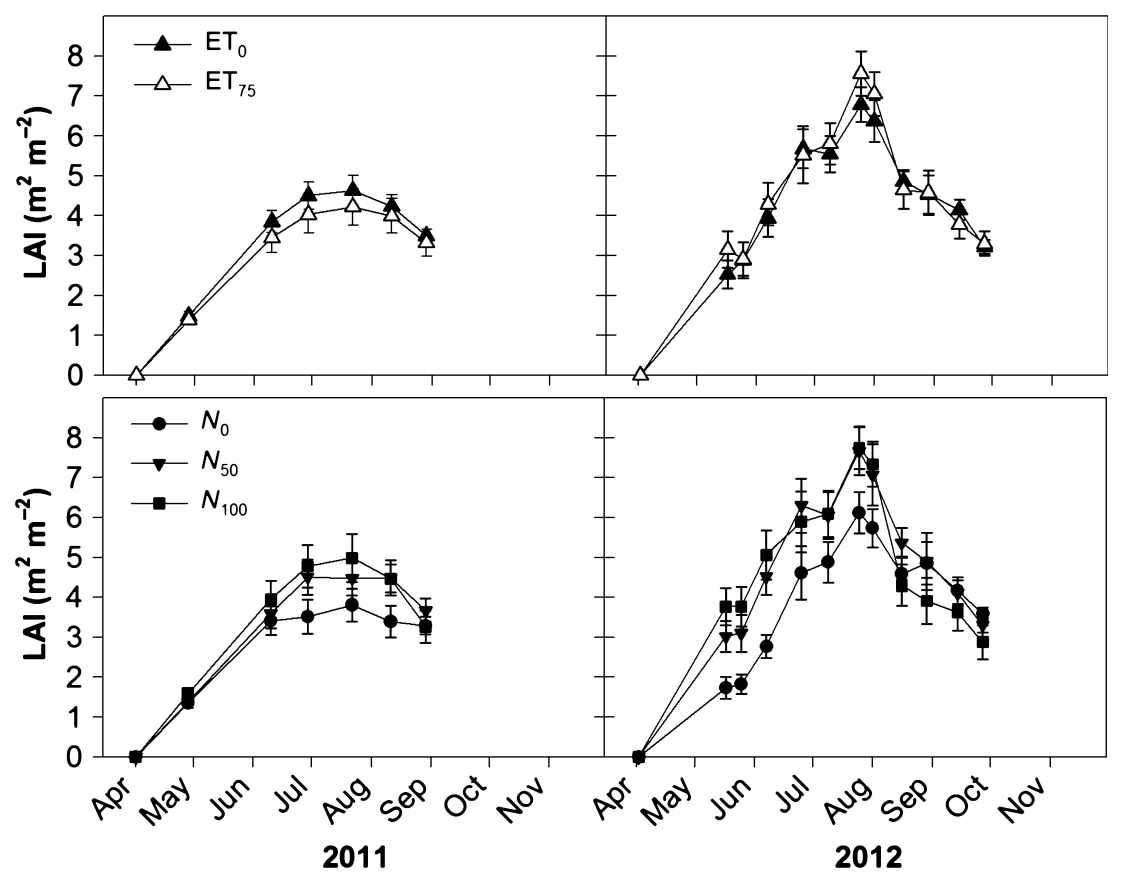

Fig. 7 Dynamics of the leaf area index (LAI) in miscanthus as function of the irrigation regime (upper panels) and the nitrogen fertilization rate (lower panels) for the second (2011) and third (2012) growing seasons. $\mathrm{ET}_{0}$ and $\mathrm{ET}_{75}$ represent the two irrigation regimes, i.e. $0 \%$ and $75 \%$ of the potential evapotranspiration respectively. $\mathrm{N}_{0}, \mathrm{~N}_{50}, \mathrm{~N}_{100}$ represent 0,50 and $100 \mathrm{~kg} \mathrm{~N}$ ha ${ }^{-1}$, respectively. Vertical bars represent the standard error $(n=3)$.

biomass accumulation in the next years (Beale \& Long, 1997; Himken et al., 1997; Strullu et al., 2011; Dohleman et al., 2012).

The detrimental effects of drought conditions on miscanthus plants lacking a well established root system have been recognized (Mann et al., 2013a). Mantineo et al. (2009) stated how irrigation in the first 3 years after the establishment affected miscanthus belowground growth and size, and the same authors found good aboveground yields during the fourth and fifth years (around 27 and $18 \mathrm{Mg} \mathrm{ha}^{-1}$ ) when no irrigation was given. These findings are corroborated by Mann et al. (2013b) who investigated the root system dynamics of miscanthus in response to rainfed and irrigated conditions, and highlighted no roots development below a depth of $1.2 \mathrm{~m}$ under rainfed conditions, while given supplemental irrigation during the establishment, miscanthus was able to develop roots $3 \mathrm{~m}$ down. Therefore, miscanthus growth patterns in sandy-loam soil (Experiment 1) highlighted the importance of supplying irrigation water also during the years following the establishment.

However, in soils characterized by a good water holding capacity (Experiment 2), revealed that irrigation water had no influence on crop productivity. Previous studies conducted in the Mediterranean (central and 
southern Italy) comparing irrigated and rainfed miscanthus crops gave ambiguous results. In fact, in southern Italy, two- and three-year old crops responded to irrigation only when water supply exceeded $440 \mathrm{~mm}$ (Cosentino et al., 2007) or when precipitation during the growing season was rather limited (around $400 \mathrm{~mm}$ ) (Mantineo et al., 2009). The importance of precipitation for miscanthus grown in Mediterranean was confirmed by Petrini et al. (1996) who compared rainfed and irrigated miscanthus in two different locations in central Italy. In 2-year old crops no differences in the aboveground yield were recorded at the site with a higher precipitation $(>420 \mathrm{~mm})$, while a $58 \%$ increase in aboveground dry yield was observed in irrigated miscanthus at the site with a lower precipitation (around $313 \mathrm{~mm}$ ). Finally, in our experimental site, Ercoli et al. (1999), when comparing the effect of irrigation and nitrogen fertilization on miscanthus yield, observed an increase in about $20 \%\left(+4.5 \mathrm{Mg} \mathrm{ha}^{-1}\right)$ in irrigated vs. rainfed plots harvested in autumn. This is consistent with our results: when precipitation during the growing season was rather low $(\sim 164 \mathrm{~mm})$ and similar to that reported by Ercoli et al. (1999) ( 173 mm), plots receiving irrigation increased their dry yield by around 15\% compared to rainfed plots. Conversely, in 2012 when precipitation was much greater $(\sim 400 \mathrm{~mm})$ miscanthus under $\mathrm{ET}_{0}$ and $\mathrm{ET}_{75}$ yielded nearly the same.

Overall, our study and the literature stress the importance of determining miscanthus yield responses to $\mathrm{N}$ fertilization rates on a site-by-site basis, as many factors can confound the fertilization effect (e.g. soil texture, soil organic matter and nutrient contents, mineralization rate, crop rooting depth, harvest time, crop age, etc.) (Zub \& Brancourt-Hulmel, 2010; Anderson et al., 2011; Cadoux et al., 2012; Maughan et al., 2012). Most of the trials have been conducted in continental climates. In these environments crop responses to modest $\mathrm{N}$ fertilization rates $\left(40-100 \mathrm{~kg} \mathrm{~N}^{-1}\right.$ ) have been highlighted by Acaroğlu \& Şemi Aksoy (2005) and Boehmel et al. (2008). Through the boundary line approach, Lewandowski \& Schmidt (2006) reported increasing miscanthus yields up to $110 \mathrm{~kg} \mathrm{~N}^{-1}$. Similarly, Schwarz et al. (1994) found that miscanthus yields increased significantly from 0 to $90 \mathrm{~kg} \mathrm{~N}^{-1}$, and decreased with 120 and $180 \mathrm{~kg} \mathrm{~N}^{-1}$. In a article by Arundale et al. (2013) who summarized multiyear trials in Illinois (USA) a positive, though small, yield response to $\mathrm{N}$ fertilization was highlighted with high rates (around $200 \mathrm{~kg} \mathrm{~N} \mathrm{ha}^{-1}$ ). Several studies have, however, found no influence of $\mathrm{N}$ fertilization on crop yield at harvest (Himken et al., 1997; Heaton et al., 2004; Christian et al., 2008; Strullu et al., 2011; Behnke et al., 2012; Kering et al., 2012; Maughan et al., 2012; Larsen et al., 2013).
Our results therefore confirmed a general trend reported in the literature. Although in the Mediterranean only a few trials have investigated the $\mathrm{N}$ fertilization effect on miscanthus yields, our results agree with those of Danalatos et al. (2007) and Mantineo et al. (2009) who found no yield increase in young miscanthus stands (1-5 years old). Conversely, positive responses to $\mathrm{N}$ fertilization were observed by Cosentino et al. (2007) and Ercoli et al. (1999), particularly when water was not limited. However, these results may differ from ours due to the lower $\mathrm{N}$ availability in the soil (Cosentino et al., 2007) or to the higher fertilization rates (Ercoli et al., 1999). On the other hand, our results corroborate the importance of $\mathrm{N}$ fertilization for LAI development, as observed by Wang et al. (2012), at least for the first few years after the establishment, and, in addition by the findings of Strullu et al. (2013) who reported how LAI expansion in miscanthus depended on the nitrogen accumulated in the aboveground biomass.

Our results also highlighted that, although $\mathrm{N}$ fertilization can lead to higher dry yield (i.e. two-year old crop in Experiment 2), whenever fertilizer application is not limited a significant reduction in the agronomic efficiency of the fertilization $\left(A_{E}\right)$ is likely to occur. These findings are consistent with other studies that found a positive effect of $\mathrm{N}$ fertilization on miscanthus yields. For instance, when calculating the $A_{E}$ from data reported by Arundale et al. (2013) values are around $45 \mathrm{~kg} \mathrm{~kg}_{\mathrm{N}}^{-1}$ when $67 \mathrm{~kg} \mathrm{~N}^{-1}$ are applied, while they drop to $30 \mathrm{~kg} \mathrm{~kg}_{\mathrm{N}}^{-1}$ when 134 and $202 \mathrm{~kg} \mathrm{~N} \mathrm{ha}^{-1}$ are distributed. In addition, the observed differences in terms of the $A_{E}$ between the 2 years of investigation (Experiment 2) confirmed how miscanthus yield responses to $\mathrm{N}$ fertilization may be affected by the amount and the distribution of precipitation during the growing season.

The aboveground biomass yield of miscanthus normally peaks between August and October, and then decreases to lower values in winter (Heaton et al., 2008; Miguez et al., 2008; Zub \& Brancourt-Hulmel, 2010). This reduction is mainly due to the translocation of assimilates, leaf detachment and shoot-tip fall (Beale \& Long, 1997; Kahle et al., 2001; Strullu et al., 2011). Overall, in our study the decrease in aboveground biomass due to delayed harvest (from $A_{1}$ to $W$ ) stood around $30-40 \%$. This basically concurs with the range reported in the literature. In central and northern European conditions, a 25-35\% yield reduction has been generally observed (Schwarz et al., 1994; Himken et al., 1997; Clifton-Brown et al., 2000; Kahle et al., 2001; Strullu et al., 2011). However, it appears that the largest proportional decrease in dry yield from early to late harvest takes place at lower latitudes which have a greater yield potential and a higher amount of leaves at early harvest 
(Miguez et al., 2008). For instance Lewandowski et al. (2003b) observed miscanthus yield losses up to $35 \%$ in Portugal compared to $24 \%$ and $27 \%$ in Germany and England, respectively. Our results support this hypothesis.

When accounting for yield losses in delayed harvests, the number of days between autumn and winter harvests is also fundamental (Lewandowski et al., 2003b). Our results highlighted a steady decline in harvestable biomass of $0.27-0.31 \%$ per day, which is consistent with data reported by Lewandowski et al. (2003b) and Clifton-Brown et al. (2004, 2007), i.e. $0.30-0.39 \%$ per day. The recorded decline corresponds to a yield decrease of around $0.07 \mathrm{Mg} \mathrm{ha}^{-1}$ per day of delay, which is the same figure as reported by Heaton et al. (2004) for miscanthus.

Our results confirmed an increase in dry matter content due to delayed harvests (Lewandowski \& Kicherer, 1997; Lewandowski et al., 2003b; Smith \& Slater, 2011). However, if we assume a dry matter threshold for combustion equal to 25-30\% (Lewandowski et al., 2003a) only a winter harvest would be suitable, unless the biomass is left to dry or forcibly dried. For other uses (i.e. bioethanol) early harvests may also be appropriate, although this negates carbon cycling to soil through litterfall (around 3-5 Mg ha ${ }^{-1}$ ) (Kahle et al., 2001; Amougou et al., 2012) and may negatively affect the storage of belowground resources (Strullu et al., 2011).

In conclusion, in the Mediterranean, (i) soil and site characteristics, such as soil texture, soil hydraulic properties, presence and depth of the water table, appear to be the main drivers affecting miscanthus yield and management; (ii) the choice of $\mathrm{N}$ fertilization should be driven by economic and environmental factors, through the evaluation of nutrient removal with the harvest; (iii) the harvest window of miscanthus is wide and despite the optimal harvest time being influenced by the biomass end use, other long-term considerations should be taken into account, such as the yield stability and the maintenance of soil fertility.

\section{Acknowledgements}

This article has been partly funded under the EU seventh Framework Programme by the LogistEC project $\mathrm{N}^{\circ} 311858$ : Logistics for Energy Crops' Biomass. The views expressed in this article are the sole responsibility of the authors and do not necessary reflect the views of the European Commission.

A special thank is also due to the technical staff of the CRIBE and of the Institute of Life Sciences, Fabio Taccini, Sergio Cattani and Cristiano Tozzini and the Land Lab group within the Institute of Life Sciences, particularly Federico Triana, Simona Bosco, Ricardo Villani, Valentina Giulietti, Federico Dragoni and Maria Valentina Lasorella for their help in the field work and their valuable comments and suggestions.

\section{References}

Acaroğlu M, Şemi Aksoy A (2005) The cultivation and energy balance of Miscanthus $\times$ giganteus production in Turkey. Biomass and Bioenergy, 29, 42-48.

Allen RG, Pereira LS, Raes D, Smith M (1998) Crop evapotranspiration - Guidelines for computing crop water requirements - FAO Irrigation and drainage paper 56. FAO, Rome, Italy.

Amougou N, Bertrand I, Cadoux S, Recous S (2012) Miscanthus $\times$ giganteus leaf senescence, decomposition and $\mathrm{C}$ and $\mathrm{N}$ inputs to soil. Global Change Biology Bioenergy, 4, 698-707.

Anderson E, Arundale R, Maughan M, Oladeinde A, Wycislo A, Voigt T (2011) Growth and agronomy of Miscanthus $\times$ giganteus for biomass production. Biofuels, 2, 167-183.

Angelini LG, Ceccarini L, Nassi O Di Nasso N, Bonari E (2009) Comparison of Arundo donax L. and Miscanthus $\times$ giganteus in a long-term field experiment in Central Italy: analysis of productive characteristics and energy balance. Biomass and Bioenergy, 33, 635-643.

Arundale R, Dohleman F, Voigt T, Long SP (2013) Nitrogen fertilization does significantly increase yields of stands of Miscanthus $\times$ giganteus and Panicum virgatum in multiyear trials in Illinois. Bioenergy Research, 7, 408-416.

Bagnouls F, Gaussen H (1957) Les climats biologiques et leur classification. Annales de Géographie, 355, 193-220.

Beale CV, Long SP (1997) Seasonal dynamics of nutrient accumulation and partitioning in the perennial C4-grasses Miscanthus $\times$ giganteus and Spartina cynosuroides. Biomass and Bioenergy, 12, 419-428.

Behnke GD, David MB, Voigt TB (2012) Greenhouse gas emissions, nitrate leaching, and biomass yields from production of Miscanthus $\times$ giganteus in Illinois, USA. Bioenergy Research, 5, 801-813.

Boehmel C, Lewandowski I, Claupein W (2008) Comparing annual and perennial energy cropping systems with different management intensities. Agricultural Systems, 96, 224-236.

Brosse N, Dufour A, Meng X, Sun Q, Ragauskas A (2012) Miscanthus: a fast-growing crop for biofuels and chemicals production. Biofuels, Bioproducts and Biorefining, 6, 580-598.

Cadoux S, Riche AB, Yates NE, Machet J-M (2012) Nutrient requirements of Miscanthus $\times$ giganteus: conclusions from a review of published studies. Biomass and Bioenergy, 38, 14-22.

Christian DG, Riche AB, Yates NE (2008) Growth, yield and mineral content of Miscanthus $\times$ giganteus grown as a biofuel for 14 successive harvests. Industial Crops and Products, 28, 320-327.

Chum H, Faaij A, Moreira J et al. (2011) Bioenergy. In: IPCC Special Report on Renewable Energy Sources and Climate Change Mitigation (eds Edenhofer O, Pichs-Madruga R, Sokona Y, Seyboth K, Matschoss P, Kadner S, Zwickel T, Eickemeier P, Hansen G, Schlömer S, von Stechow C), pp. 209-332. Cambridge University Press, Cambridge, United Kingdom and New York, NY, USA.

Clifton-Brown JC, Lewandowski I (2000) Water use efficiency and biomass partitioning of three different Miscanthus genotypes with limited and unlimited water supply. Annals of Botany, 86, 191-200.

Clifton-Brown JC, Neilson B, Lewandowski I, Jones MB (2000) The modelled productivity of Miscanthus $\times$ giganteus (GREEF et DEU) in Ireland. Industial Crops and Products, 12, 97-109.

Clifton-Brown JC, Lewandowski I, Andersson B et al. (2001) Performance of 15 Miscanthus genotypes at five sites in Europe. Agronomy Journal, 93, 1013-1019.

Clifton-Brown JC, Stampfl PF, Jones MB (2004) Miscanthus biomass production for energy in Europe and its potential contribution to decreasing fossil fuel carbon emissions. Global Change Biology, 10, 509-518.

Clifton-Brown JC, Breuer J, Jones MB (2007) Carbon mitigation by the energy crop, Miscanthus. Global Change Biology, 13, 2296-2307.

Cosentino SL, Patanè C, Sanzone E, Copani V, Foti S (2007) Effect of soil water content and nitrogen supply on the productivity of Miscanthus $\times$ giganteus Greef and Deu. in a Mediterranean environment. Industrial Crops and Products, 25, 75-88.

Danalatos NG, Dalianis C, Kyritsis S (1996) Growth and biomass productivity of Miscanthus sinensis 'giganteus' under optimum cultural management in north-eastern Greece. In: Biomass for Energy and the Environment (eds Chartier P, Ferrero GL, Henius UM, Hultberg S, Sachau J, Wiinblad M), pp. 548-553. Pergamon, New York, NY, USA.

Danalatos NG, Archontoulis SV, Mitsios I (2007) Potential growth and biomass productivity of Miscanthus $\times$ giganteus as affected by plant density and N-fertilization in central Greece. Biomass and Bioenergy, 31, 145-152. 
Davis SC, Boddey RM, Alves BJR et al. (2013) Management swing potential for bioenergy crops. Global Change Biology Bioenergy, 5, 623-638.

Delogu G, Cattivelli L, Pecchioni N, de Falcis D, Maggiore T, Stanca AM (1998) Uptake and agronomic efficiency of nitrogen in winter barley and winter wheat. European Journal of Agronomy, 9, 11-20.

Dohleman FG, Heaton EA, Arundale RA, Long SP (2012) Seasonal dynamics of above- and below-ground biomass and nitrogen partitioning in Miscanthus $\times$ giganteus and Panicum virgatum across three growing seasons. Global Change Biology Bioenergy, 4, 534-544.

Ercoli L, Mariotti M, Masoni A, Bonari E (1999) Effect of irrigation and nitrogen fertilization on biomass yield and efficiency of energy use in crop production of Miscanthus. Field Crops Research, 63, 3-11.

Gomez KA, Gomez AA (1984) Statistical procedures for agricultural research. Wiley, New York, NY, USA.

Heaton E, Voigt T, Long SP (2004) A quantitative review comparing the yields of two candidate C-4 perennial biomass crops in relation to nitrogen, temperature and water. Biomass and Bioenergy, 27, 21-30.

Heaton EA, Dohleman FG, Long SP (2008) Meeting US biofuel goals with less land: the potential of Miscanthus. Global Change Biology, 14, 2000-2014.

Heaton EA, Dohleman FG, Miguez AF et al. (2010) Miscanthus: a promising biomass crop. Advances in Botanical Research, 56, 75-137.

Himken M, Lammel J, Neukirchen D, Czypionka-Krause U, Olfs HW (1997) Cultivation of Miscanthus under west European conditions: seasonal changes in dry matter production, nutrient uptake and remobilization. Plant and Soil, 189, 117-126.

Kahle P, Beuch S, Boelcke B, Leinweber P, Schulten HR (2001) Cropping of Miscanthus in Central Europe: biomass production and influence on nutrients and soil organic matter. European Journal of Agronomy, 15, 171-184.

Karp A, Shield I (2008) Bioenergy from plants and the sustainable yield challenge. New Phytologist, 179, 15-32.

Kering MK, Butler TJ, Biermacher JT, Guretzky JA (2012) Biomass yield and nutrien removal rates of perennial grasses under nitrogen fertilization. Bioenergy Research, 5, 61-70.

Larsen S, Jørgensen U, Kjeldsen J, Lærke P (2013) Long-term miscanthus yields influenced by location, genotype, row distance, fertilization and harvest season Bioenergy Research, 7, 620-635.

Lewandowski I, Heinz A (2003) Delayed harvest of miscanthus-influences on biomass quantity and quality and environmental impacts of energy production European Journal of Agronomy, 19, 45-63.

Lewandowski I, Kicherer A (1997) Combustion quality of biomass: practical relevance and experiments to modify the biomass quality of Miscanthus $\times$ giganteus. European Journal of Agronomy, 6, 163-177.

Lewandowski I, Schmidt U (2006) Nitrogen, energy and land use efficiencies of miscanthus, reed canary grass and triticale as determined by the boundary line approach. Agriculture, Ecosystems \& Environment, 112, 335-346.

Lewandowski I, Scurlock JMO, Lindvall E, Christou M (2003a) The developmen and current status of perennial rhizomatous grasses as energy crops in the US and Europe. Biomass and Bioenergy, 25, 335-361.

Lewandowski I, Clifton-Brown JC, Andersson B et al. (2003b) Environment and harvest time affects the combustion qualities of genotypes. Agronomy Journal, 95, $1274-1280$

Mann JJ, Barney JN, Kyser GB, di Tomaso JM (2013a) Miscanthus $\times$ giganteus and Arundo donax shoot and rhizome tolerance of extreme moisture stress. Global Change Biology Bioenergy, 5, 693-700.

Mann JJ, Barney JN, Kyser GB, di Tomaso JM (2013b) Root system dynamics of Miscanthus $\times$ giganteus and Panicum virgatum in response to rainfed and irrigated conditions in California. Bioenergy Research, 6, 678-687.

Mantineo M, D'Agosta GM, Copani V, Patanè C, Cosentino SL (2009) Biomass yield and energy balance of three perennial crops for energy use in the semi-arid Mediterranean environment. Field Crops Research, 114, 204-213.

Maughan M, Bollero G, Lee DK et al. (2012) Miscanthus giganteus productivity: the effects of management in different environments. Global Change Biology Bioenergy, $4,253-265$.

deMendiburu F (2013) Agricolae: Statistical procedures for agricultural research. R package version 1.1-4. Available at: http://CRAN.R-project.org/package=agricolae (accessed 25 October 2013).
Miguez FE, Villamil MB, Long SP, Bollero GA (2008) Meta-analysis of the effects of management factors on Miscanthus $\times$ giganteus growth and biomass production Agricultural and Forest Meteorology, 148, 1280-1292.

Nassi o Di Nasso N, Roncucci N, Triana F, Tozzini C, Bonari E (2011) Productivity of giant reed (Arundo donax L.) and miscanthus (Miscanthus $x$ giganteus Greef et Deuter) as energy crops: growth analysis. Italian Journal of Agronomy, 6, 141-147.

Petrini C, Bazzocchi R, Bonari E, Ercoli L, Masoni A (1996) Effect of irrigation and nitrogen supply on biomass production from Miscanthus in northern-central Italy. Agricoltura Mediterranea, 126, 275-284.

R Core Team (2013) R: a language and environment for statistical computing. R Foundation for Statistical Computing, Vienna, Austria. Available at: http:// www.R-project.org/ (accessed 13 June 2013).

Ragauskas AJ, Williams CK, Davison BH et al. (2006) The path forward for biofuels and biomaterials. Science, 311, $484-489$

Richter GM, Riche AB, Dailey AG, Gezan SA, Powlson DS (2008) Is UK biofuel supply from Miscanthus water-limited? Soil Use and Management, 24, 235-245.

Rowe RL, Street NR, Taylor G (2009) Identifying potential environmental impacts of large-scale deployment of dedicated bioenergy crops in the UK. Renewable and Sustainable Energy Reviewss, 13, 271-290.

Schwarz H, Liebhard P, Ehrendorfer K, Ruckenbauer P (1994) The effect of fertilization on yield and quality of Miscanthus sinensis 'Giganteus'. Industrial Crops and Products, 2, 153-159.

Smith R, Slater FM (2011) Mobilization of minerals and moisture loss during senescence of the energy crops Miscanthus $\times$ giganteus, Arundo donax and Phalaris arundinacea in Wales, UK. Global Change Biology Bioenergy, 3, 148-157.

Strullu L, Cadoux S, Preudhomme M, Jeuffroy MH, Beaudoin N (2011) Biomass production and nitrogen accumulation and remobilisation by Miscanthus $\times$ giganteus as influenced by nitrogen stocks in belowground organs. Field Crops Research, 121, 381-391.

Strullu L, Cadoux S, Beaudoin N, Jeuffroy MH (2013) Influence of belowground nitrogen stocks on light interception and conversion of Miscanthus giganteus. European Journal of Agronomy, 47, 1-10.

Wallace J (2000) Increasing agricultural water use efficiency to meet future food production. Agriculture, Ecosystems \& Environment, 82, 105-119.

Wang D, Maughan MW, Sun JD, Feng XH, Miguez F, Lee D, Dietze MC (2012) Impact of nitrogen allocation on growth and photosynthesis of Miscanthus ( $M i^{-}$ scanthus $\times$ giganteus). Global Change Biology Bioenergy, 4, 688-697.

Zegada-Lizarazu W, Elbersen HW, Cosentino SL, Zatta A, Alexopoulou E, Monti A (2010) Agronomic aspects of future energy crops in Europe. Biofuels, Bioproducts and Biorefining, 4, 674-691.

Zub HW, Brancourt-Hulmel M (2010) Agronomic and physiological performances of different species of Miscanthus, a major energy crop. A Review. Agronomy for Sustainable Development, 30, 201-214.

\section{Supporting Information}

Additional Supporting Information may be found in the online version of this article:

Table S1. Results of the ANOVA in Experiment 1 for the aboveground dry yield in 2011 and 2012 (i.e. second and third growing seasons respectively).

Table S2. Results of the ANOVA in Experiment 2 for the aboveground dry yield in 2011 and 2012 (i.e. second and third growing years respectively).

Table S3. Results of the ANOVA in Experiment 2 for maximum LAI in 2011 and 2012 (i.e. second and third growing seasons, respectively). Maximum LAI was achieved on 22 July 2011 and 25 July 2012 